\title{
Use of induced sputum cell counts to investigate airway inflammation in asthma
}

Isabelle Pin, Peter G Gibson, Roxanne Kolendowicz, Adele Girgis-Gabardo, Judah A Denburg, Frederick E Hargreave, Jerry Dolovich

\begin{abstract}
Background Airway inflammation is considered to be important in asthma but is relatively inaccessible to study. Less invasive methods of obtaining sputum from patients unable to produce it spontaneously should provide a useful investigational tool in asthma.

Methods A method to induce sputum with inhaled hypertonic saline was modified for use in 17 asthmatic patients and 17 normal subjects who could not produce sputum spontaneously. The success rate and safety of the method, the reproducibility of cell counts, and differences in cell counts between the asthmatic and normal groups were examined. Hypertonic saline solution 3$5 \%$ was inhaled for up to 30 minutes after inhalation of salbutamol. Subjects were asked to expectorate sputum every five minutes. The quality of the sample was scored on the volume of plugs and the extent of salivary contamination. Plugs from the lower respiratory tract were selected for a total cell count and for differential cell counts of eosinophils and metachromatic cells (mast cells and basophils) in direct smears.
\end{abstract}

Results Adequate samples from the lower respiratory tract were obtained in $76 \%$ of first attempts. The mean fall in the forced expiratory volume in one second $\left(F E V_{1}\right)$ during inhalation of saline was $5 \cdot 3 \%$ and the maximum fall $20 \%$. Eosinophil and metachromatic cell counts were reproducible (reliability coefficient 0.8 and 0.7 respectively). When compared with sputum from normal subjects sputum from asthmatic patients contained a significantly higher proportion of eosinophils (mean $18.5 \%$ (SE 3.8\%) v $1.9 \%(0.6 \%)$ and metachromatic cells $(0.50 \%(0.18 \%) v 0.039 \%$ $(0 \cdot 014 \%))$. In the asthmatic group the differential eosinophil count correlated with the baseline $\mathrm{FEV}_{1}$.

Conclusion Induced sputum is capable of detecting differences in cell counts between normal and asthmatic subjects and merits further development as a potential means of assessing airway inflammation in asthma.

Airway inflammation is a major factor in the pathogenesis of asthma. Mast cell and eosinophil infiltration, epithelial damage, and mucus production are characteristic features. ${ }^{1}$ Direct examination of the inflammatory response should help to improve understanding of the pathogenesis and treatment of asthma.

In patients with stable asthma bronchial biopsy and bronchoalveolar lavage have been used to study airway inflammation ${ }^{2-4}$ but discomfort, inconvenience, and risks limit their use. Examination of sputum is a less invasive alternative, ${ }^{5}$ but sputum cannot always be produced spontaneously. When sputum is not otherwise available induced samples may allow secretions from the lower airways to be sampled.

Sputum induction by inhalation of hypertonic saline has been successfully used to diagnose Pneumocystis carinii pulmonary infections in patients infected with HIV. ${ }^{6-8}$ We adapted this method for use in asthmatic subjects and examined $(a)$ the success rate and safety of the method, $(b)$ the reproducibility of cell counts, and $(c)$ the differences in cell counts between normal and asthmatic subjects.

\section{Methods}

SUBJECTS

Seventeen normal subjects and 17 subjects with asthma were selected from among the staff (adults) and asthmatic patients and their siblings (adults or children) at the clinics of the Firestone Regional Chest and Allergy Unit and the Health Sciences Centre. All were nonsmokers or ex-smokers of more than five years. None had spontaneous sputum or symptoms of a respiratory tract infection, or had been exposed to a seasonal allergen within the last month. The normal subjects had no past or current symptoms of asthma, a forced expiratory volume in one second $\left(\mathrm{FEV}_{1}\right)>80 \%$ of predicted values, ${ }^{9}$ a ratio of $\mathrm{FEV}_{1}$ to vital capacity $>70 \%$, and normal airway responsiveness to methacholine (provocative concentration of methacholine causing a $20 \%$ fall in $\left.\mathrm{FEV}_{1}\left(\mathrm{PC}_{20}\right)>8 \mathrm{mg} / \mathrm{ml}\right)^{10}$ (table 1 ). The asthmatic subjects had a history of episodic dyspnoea with wheeze in the previous six months and a $P_{20}$ methacholine $<8 \mathrm{mg} / \mathrm{ml}$ (15 patients) or a spontaneous variability in peak expiratory flow rate (PEF of $>20 \%$ (two patients). All were taking an inhaled $\beta_{2}$ agonist when needed; 15 were treated with inhaled corticosteroid (daily dose 200-3000 $\mu \mathrm{g}$ ) and one with prednisone $5 \mathrm{mg}$ daily. Although asthma was stable in all subjects, control of the condition was good ${ }^{11}$ in only five subjects; the remaining 12 had more asthmatic symptoms 
Table 1 Characteristics of normal and asthmatic subjects

\begin{tabular}{|c|c|c|}
\hline & $\begin{array}{l}\text { Normal subjects } \\
(n=17)\end{array}$ & $\begin{array}{l}\text { Asthmatic subjects } \\
(n=17)\end{array}$ \\
\hline $\begin{array}{l}\text { No of females } \\
\text { Mean (years) (range) } \\
\text { Mean atopy score } \\
\text { Mean (SE) FEV } 1 \% \text { pred) } \\
\text { PC }_{20} \text { (geometric mean) (range) }\end{array}$ & $\begin{array}{l}9 \\
27 \cdot 3(14-58) \\
3 \cdot 6 \\
108 \cdot 9(2 \cdot 9) \\
41 \cdot 7(13->64)\end{array}$ & $\begin{array}{l}11 \\
30 \cdot 3(11-69) \\
10.9 \\
88.9(4 \cdot 1) \\
0.21(<0.03-6 \cdot 1)\end{array}$ \\
\hline
\end{tabular}

$\star$ Results of allergy prick tests expressed as sum of,$+ 1+$ corresponding to weal diameter 1-2 $\mathrm{mm}$ greater than saline control, $2+$ to $3-5 \mathrm{~mm}, 3+$ to $6-9 \mathrm{~mm}$, and $4+$ to $>9 \mathrm{~mm}$.

$\mathrm{PC}_{20}=$ provocation concentration of methacholine producing a $20 \%$ fall in $\mathrm{FEV}_{1}$.

than when at their best, an increased requirement for inhaled bronchodilator, or an $\mathrm{FEV}_{1}$ $<85 \%$ (but $>40 \%$ ) of their best recorded value.

The study was approved by St Joseph's Hospital research committee, and all subjects (parents in the case of children) gave informed consent.

STUDY DESIGN

Subjects' characteristics were documented by questionnaire, allergy prick tests with 12 common allergen extracts, ${ }^{12}$ spirometry, and a methacholine inhalation test (or diurnal variation in PEF). At a second visit, usually within one week, sputum was induced between 0800 and 1300 hours. Twelve subjects (six normal and six asthmatic) chosen at random were asked to have sputum induced on a second occasion within one week at the same time of day. If on one of the two occasions an adequate sample was not obtained the induction was carried out a third time within the same week. Cell counts were performed blind without knowledge of the clinical characteristics of the patients.

INDUCTION OF SPUTUM

Inhaled bronchodilator was withheld for six hours before the induction. $\mathrm{FEV}_{1}$ and vital capacity were measured before and 10 minutes after salbutamol inhalation (two puffs, $200 \mu \mathrm{g}$ ) and then every five minutes during inhalation of hypertonic saline solution. The hypertonic saline was nebulised with an ultrasonic nebuliser (Fisoneb, Fisons, Pickering, Ontario) on the maximum setting and was inhaled for five minute periods for up to 30 minutes. Under these conditions the mass median aerodynamic diameter was $5.9 \mu \mathrm{m}$ and the output $0.6 \mathrm{l} / \mathrm{min} .{ }^{13}$ The concentration of saline was increased at intervals of 10 minutes from $3 \%$ to $4 \%$ to $5 \%$. If the FEV fell by $>10 \%$ from the post-bronchodilator value the concentration of saline was not increased. If the FEV, fell by $>20 \%$ or if troublesome symptoms occurred nebulisation was discontinued. Ten minutes after the start of nebulisation and every five minutes thereafter subjects were asked to rinse their mouth and throat carefully and to try to cough sputum into a container. The nebulisation was stopped after 30 minutes or earlier if a sputum sample of good quality was obtained.

SPUTUM ASSAYS

The volume of sputum was recorded and the sample transferred to a Petri dish, where its macroscopic characteristics were recorded. The quality of the sample was assessed by estimating the volume of lower respiratory tract secretions and the degree of salivary contamination. The volume was assessed by the size and number of plugs; a cumulative size of $4.5 \times 9 \mathrm{~mm}$ was estimated to be necessary to perform all investigations, including total and differential counts. The quality of the sputum sample was scored by $(a)$ visual inspection and inverted microscope examination (no plugs = $0, \leqslant 4.5 \times 9 \mathrm{~mm}=1,>4.5 \times 9 \mathrm{~mm}=2) ;(b)$ salivary contamination in total cell counts defined as the percentage of squamous cells among nucleated cells $(>10 \%=0, \leqslant 10 \%=$ $1,0 \%=2) ;(c)$ salivary contamination in differential cell counts by assessing the proportion of squamous cells in the slides (too many squamous cells to permit a count $=0$, enough squamous cells to permit a count $=1$, no squamous cells $=2$ ). A sample score of $\geqslant 4$ was considered to be adequate, of 3 to be intermediate, and of $\leqslant 2$ to be inadequate.

Sputum analysis was performed as described by Gibson et al, ${ }^{5}$ except that Sputalysin (Calbiochem, San Diego, California) was used instead of trypsin to suspend the plugs for total cell counts. Formal comparison of trypsin and Sputalysin suspensions in 18 sputum samples found good agreement between the total cell counts (intraclass correlation coefficient $0 \cdot 85$ ). Differential cell counts of intact bronchial epithelial cells and leucocytes were performed by counting 400 nucleated cells on each of two slides fixed with methanol and stained with May-Grünwald-Giemsa. Two further slides were fixed with Carnoy's solution and stained with $0.5 \%$ toluidine blue in $0.7 \mathrm{~N}$ hydrochloric acid at pH $0 \cdot 1$, and 1500 nucleated cells were counted on to each to obtain a differential count of metachromatic cells.

\section{STATISTICAL ANALYSES}

Differential and total cell counts were calculated as arithmetic means with $95 \%$ confidence intervals. $\mathrm{PC}_{20}$ results were $\log$ transformed for analysis. The relation between categorical data (age, sex, diagnosis of asthma, and scores) was examined by the $\chi^{2}$ test. The reproducibility of sputum cell counts was examined by analysis of variance with calculation of the coefficient of reliability, $R$ (the ratio of the variance of cell counts between subjects to the total variance in cell counts (subjects and error variance)), higher values indicating higher reliability. ${ }^{14}$ For the study of reproducibility the two samples with the highest scores were selected for each subject. For the comparison of counts between normal and asthmatic subjects and their relation to $\mathrm{FEV}_{1}$, the ratio of $F E V_{1}$ to vital capacity and $\mathrm{PC}_{20}$ the counts used were from the first adequate sample collected (score $\geqslant 4$ ) when there was more than one attempt or from adequate or intermediate samples when there was only one attempt. Two tailed unpaired $t$ tests were used to compare cell counts between groups. Correlations were examined by least square linear regression analysis. Significance was accepted at the $95 \%$ level. 
Figure 1 Identity plots for eosinophils (top) and metachromatic cells (bottom): counts (as percentages) from adequate sputum samples collected on two days within one week; $R$ is the coefficient of reliability.

\section{Results}

SAFETY AND SUCCESS OF THE METHOD

The mean volume of nebulised hypertonic saline was $12 \mathrm{ml}$ per induction. Only one asthmatic subject developed a mild spontaneous cough during the process. The most common complaint was of a salty taste. The mean fall in $\mathrm{FEV}_{1}$ during nebulisation was 0 in
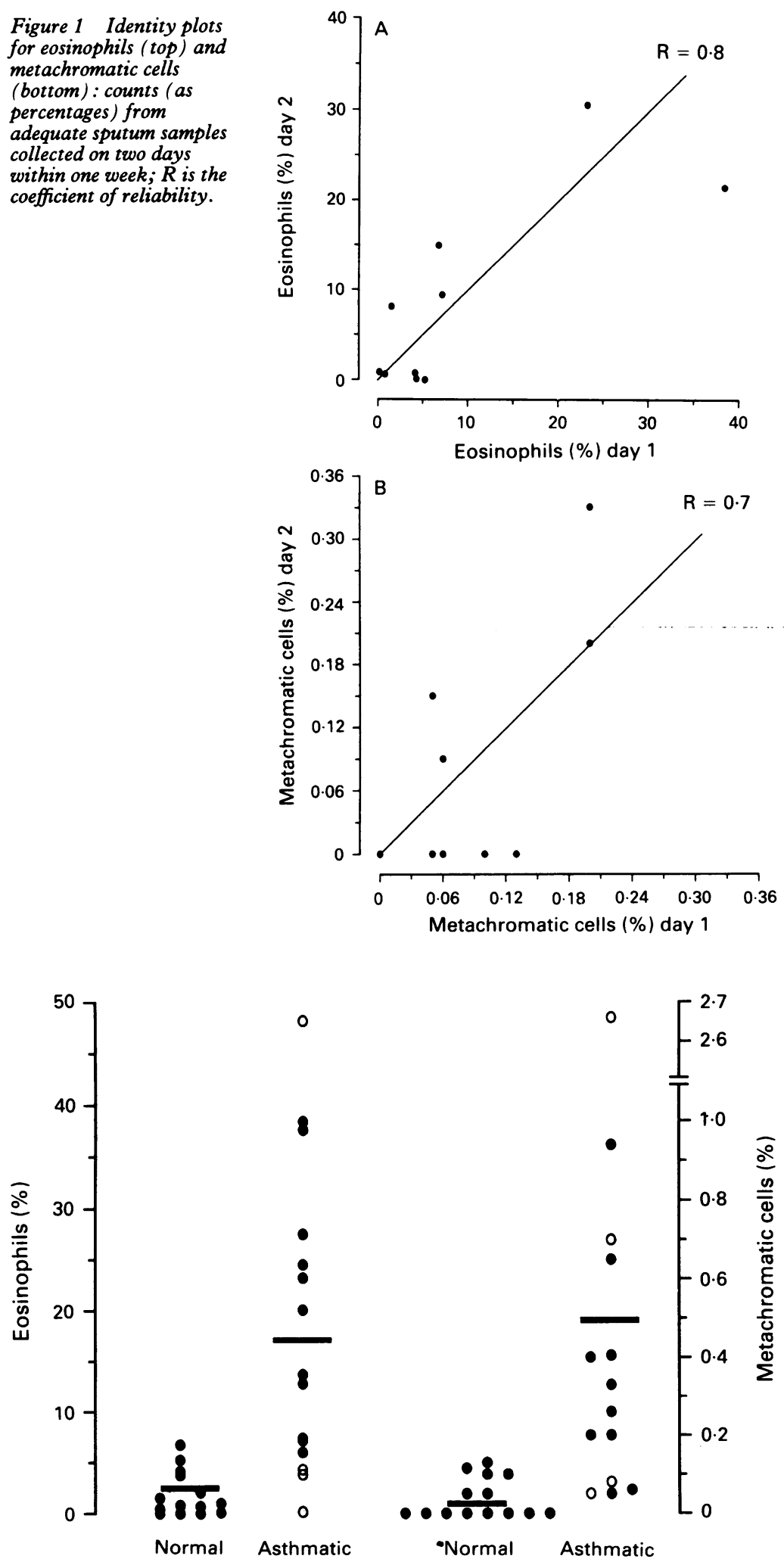

Figure 2 Differential cell counts of eosinophils and metachromatic cells in normal and asthmatic subjects. The solid bar represents the mean value for the counts in the group. Open circles represent patients with controlled asthma, closed circles patients with uncontrolled asthma. the normal subjects and $5 \cdot 3 \%$ in the asthmatic subjects. The nebulisation had to be stopped only once because the fall in $\mathrm{FEV}_{1}$ exceeded $20 \%(30 \%)$; the fall was quickly reversed with an inhaled $\beta_{2}$ agonist.

Of the first 34 attempts at sputum inductions, 26 produced adequate samples, one an intermediate sample, and seven inadequate samples. A history of spontaneous sputum production $\left(\chi^{2}=7.65, \mathrm{p}<0.05\right)$ but not age, sex, or the presence of asthma $\left(\chi^{2}=0.42,1.5,0.24\right.$ respectively; df 2 ; NS) was associated with a better quality of sample.

Of the 12 adults with repeated studies, eight had adequate samples on the first two occasions, two had intermediate samples on the first occasion but adequate samples on subsequent attempts, and one asthmatic subject had only one adequate sample out of two. One normal subject had no adequate sample despite three attempts.

\section{REPRODUCIBILITY OF SPUTUM CELL COUNTS}

There was reasonably good reproducibility of differential counts of eosinophils $(R=0.8)$, metachromatic cells $(R=0.7)$ (figure 1 ), macrophages $(R=0.71)$, and polymorphonuclear cells $(R=0.73)$. The reproducibility of total cell counts $(R=0.25)$ was less satisfactory.

\section{COMPARISON OF CELL COUNTS BETWEEN} ASTHMATIC AND NORMAL SUBJECTS

There was no difference between asthmatic and normal subjects in total or absolute cell counts. The analyses have therefore been expressed only as differential counts. The differential counts of eosinophils and metachromatic cells from asthmatic subjects were significantly higher than those from normal subjects (fig 2; table 2) and the differential macrophage count was lower $(\mathrm{p}=0.007,0.02$, and 0.002 respectively). There was a trend for more neutrophils in the sputum from asthmatic subjects, but the difference was not significant $(p=0.051)$. There were no significant differences in total cell counts, differential counts of intact bronchial epithelial cells, or lymphocytes between the two groups.

The relations between cell counts and clinical characteristics were examined. Mean eosinophil and metachromatic cell counts did not differ significantly between patients with controlled and patients with uncontrolled asthma. There was an inverse correlation between the eosinophil count (\%) and both FEV, (\% predicted values) and the ratio of $\mathrm{FEV}_{1}$ to vital capacity before bronchodilator on the day the sputum was sampled $(r=-0.71$, $p<0.001$ and $r=-0.57, p=0.006$ respectively). This relation was present for $F_{E V}$ in the asthmatic group only $(r=-0.61$, $\mathrm{p}=0.01$ ) (fig 3). There was a weak correlation between the metachromatic cell count $(\%)$ and $\mathrm{PC}_{20}$ when it was measurable $(\mathrm{r}=-0.49$, $\mathrm{p}=0.03$ ), but not when the asthmatic group alone was analysed. There was no relation between eosinophil or metachromatic cell counts and either the allergy skin index or dose of inhaled corticosteroid. 
Table 2 Total and differential cell counts in induced sputum. Values are means (95\% confidence intervals)

\begin{tabular}{|c|c|c|c|c|c|c|c|}
\hline \multirow[b]{2}{*}{ Group } & \multirow[b]{2}{*}{$\begin{array}{l}\text { Total cell count } \\
\left(\times 10^{6} / \mathrm{ml}\right)\end{array}$} & \multicolumn{6}{|c|}{ Differential cell counts (\% of total nucleated cells) } \\
\hline & & $\begin{array}{l}\text { Bronchial } \\
\text { epithelial cell }\end{array}$ & Neutrophil & Macrophage & Lymphocyte & Eosinophil & $\begin{array}{l}\text { Metachromatic } \\
\text { cell }\end{array}$ \\
\hline $\begin{array}{l}\text { Normal } \\
(n=14) \\
\text { Asthmatic }\end{array}$ & $4.5(2.3$ to $6 \cdot 8)$ & $5.3(1.8$ to $8 \cdot 8)$ & $11 \cdot 1(5 \cdot 1$ to $17 \cdot 0)$ & $79 \cdot 8(73 \cdot 5$ to $86 \cdot 2)$ & $1.55(0.7$ to 2.4$)$ & $1.9(0.6$ to 3.2$)$ & $0.039(0.009$ to 0.068$)$ \\
\hline$(n=15)$ & $4 \cdot 5(2 \cdot 0$ to $7 \cdot 1)$ & $2.9(1.8$ to 4.0$)$ & $23.5(12 \cdot 2 \text { to } 34 \cdot 7)^{\star}$ & $56.7(47.5$ to 65.9$) \dagger$ & $0.5(0.2$ to 0.9$)$ & $18 \cdot 3(10 \cdot 2$ to $26 \cdot 4) \ddagger$ & $0.50(0.11$ to 0.89$) \S$ \\
\hline
\end{tabular}

${ }^{\star} \mathrm{p}=0.051 . \dagger \mathrm{p}=0.002 . \ddagger \mathrm{p}=0.007 . \S \mathrm{p}=0.02$.

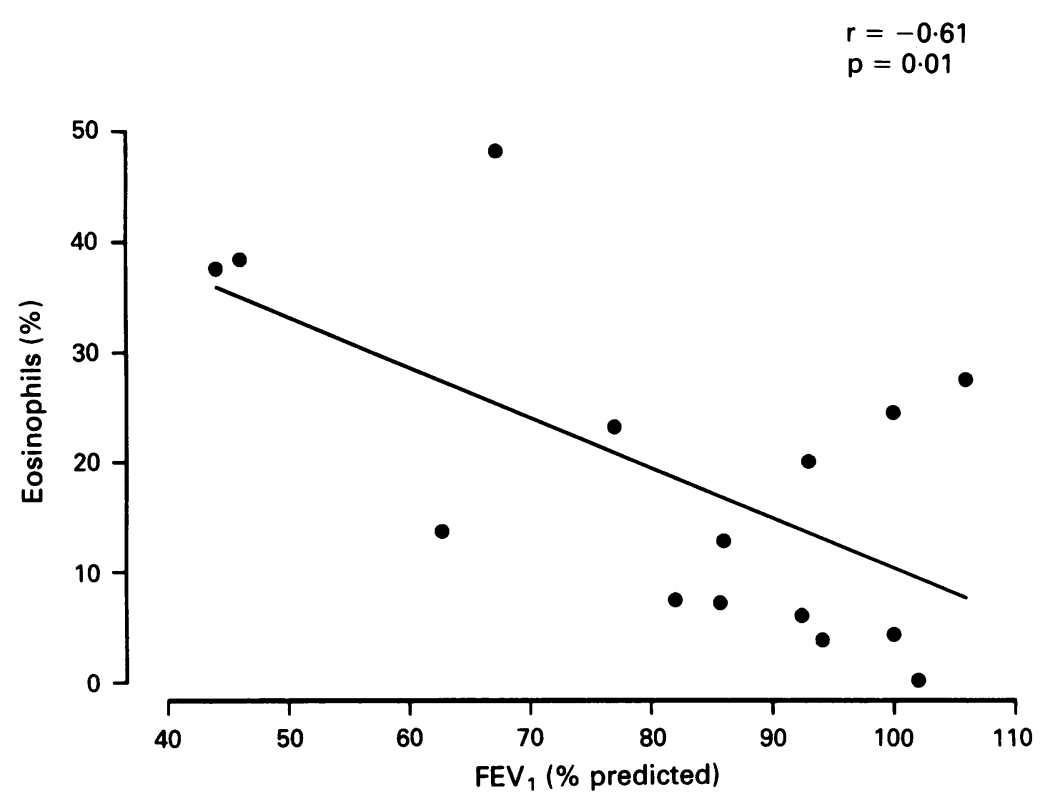

Figure 3 Plot of the differential counts of eosinophils (as percentages) against $F E V, \%$ predicted measured before sputum collection in the asthmatic group. $r$ is the correlation coefficient; the line and p value correspond to the fitted regression equation.

\section{Discussion}

This is the first time that an attempt has been made to use induced sputum samples to examine the inflammatory response in asthma. The results show that such samples differed between asthmatic and normal subjects. Further development and use of the technique is indicated, especially as the only alternatives are more invasive, with discomfort and risk.

The mechanism whereby inhalation of an aerosol of hypertonic saline induces sputum is not known. It may increase water flux into the lumen of the airways and free or increase the volume of secretions so that they can be expectorated. An adequate or intermediate sample was obtained from the lower respiratory tract in $77 \%$ of first attempts and in $84 \%$ of second attempts.

Inhalation of hypertonic saline causes airway constriction in some asthmatic patients, ${ }^{15-17}$ and to try to prevent this we gave an inhaled $\beta_{2}$ agonist before the procedures and increased the concentration of hypertonic saline gradually while monitoring the $\mathrm{FEV}_{1}$. One asthmatic patient (with a low ratio of $\mathrm{FEV}_{1}$ to vital capacity and $\mathrm{PC}_{20}$ ) had a fall in $\mathrm{FEV}_{1}$ of $>20 \%$, which reversed quickly with an inhaled bronchodilator. The mean fall in $\mathrm{FEV}_{1}$ was $5.3 \%$.

The method showed an increased proportion of eosinophils and metachromatic cells in sputum from asthmatic subjects compared with normal subjects. This result is similar to those previously obtained with spontaneous sputum samples," bronchoalveolar lavage fluid, ${ }^{2318-21}$ and bronchial biopsy specimens. ${ }^{4}$ The mean percentages of eosinophils and metachromatic cells were higher in induced sputum than in bronchoalveolar lavage samples in patients with mild stable asthma, in whom eosinophils account for $<5 \%$ and metachromatic cells $<0.5 \%$ of the cells. ${ }^{319} 20$ They were lower than sputum counts during an exacerbation of asthma. ${ }^{5}$

Despite the clear difference in mean differential eosinophil and metachromatic cell counts between normal and asthmatic subjects there was overlap between the two populations. Similar overlap was found with bronchoalveolar lavage samples ${ }^{2}$ and bronchial biopsy specimens. ${ }^{22}$ This may reflect normal variation, subclinical disease, inhibition by corticosteroid treatment, ${ }^{23-26}$ or variability in sputum induction and cell counting.

Lack of reproducibility of sputum cell counts has been recognised for some time. ${ }^{27}$ The distribution of cells within the specimen may not be homogeneous or the recognition of different cell types may not be accurate, or both. The method of sputum examination in our study was similar to that used in a previous study on spontaneous sputum, in which the reproducibility of total and differential cell counts was good. ${ }^{5}$ Microscopic selection of the plugs for analysis is considered to be essential to ensure that only lower respiratory tract secretions rather than saliva are selected for the analysis. ${ }^{527}$ Reproducibility in our study, especially of total cell counts, was not as good possibly because induced sputum is less homogeneous than spontaneously produced sputum. Further investigation of the methods and factors determining reproducibility are required.

Our study was not designed to examine relations between induced sputum cell counts and clinical and physiological characteristics of asthma. Nevertheless, eosinophil counts correlated with the degree of airflow obstruction, as has been observed in bronchoalveolar lavage samples. ${ }^{2}$ Our observations suggest that induced sputum may have a role in the study of asthma and, perhaps, other lung diseases. 
We thank the subjects for participating and Fisons Canada for supplying the nebulisers. The study was supported by the Medical Research Council of Canada. PGG was supported by the Canadian Lung Association and IP by Fondation Marc Braillon and Fisons (France). Mrs Laurie Whitely provided excellent secretarial help.

1 Reid LM, Gleich GJ, Hogg J, Kleinerman J, Laitinen LA. Pathology. In: Holgate ST, ed. The role of inflammatory processes in airway hyperresponsiveness.

2 Kirby JG, Hargreave FE, Gleich GJ, O'Byrne PM. Bronchoalveolar cell profiles of asthmatic and nonasthmatic subjects. Am Rev Respir Dis 1987;136:379-83.

3 Wardlaw AJ, Dunnette S, Gleich GJ, Collins JV, Kay AB. Eosinophils and mast cells in bronchoalveolar lavage in subjects with mild asthma. Relationship to bronchial subjects with mild asthma. Relationship to bro

4 Beasley R, Roche WR, Roberts JA, Holgate ST. Cellular events in the bronchi in mild asthma and after bronchial provocation. Am Rev Respir Dis 1989;139:806-17.

5 Gibson PG, Girgis-Gabardo A, Morris MM, Mattoli S, Kay $\mathrm{JM}$, Dolovich J, et al. Cellular characteristics of sputum from patients with asthma and chronic bronchitis. Thorax 1989;44:689-92.

6 Leigh TR, Hume C, Gazzard B, Parsons P, Husain OAN, Collins JV. Sputum induction for the diagnosis of Pneumocystis carinii pneumonia. Lancet 1989;ii:205-6.

7 Bigby TD, Margolskee D, Curtis JL, Michael PF, Sheppard $\mathrm{D}$, Hadley WK, et al. The usefulness of induced sputum in the diagnosis of Pneumocystis carinii pneumonia in patients with the acquired imunodeficiency syndrome. $\mathrm{Am}$ patients with the acquired imunod
Rev Respir Dis 1986;133:515-8.

8 Pitchenik AE, Ganjei P, Torres A, Evans DA, Rubin E, Baier H. Sputum examination for the diagnosis of Pneumocystis carinii pneumonia in the acquired immunodeficiency syndrome. Am Rev Respir Dis 1986;133: 226-9.

9 Crapo RO, Morris AH, Gardner RM. Reference spirometric values using techniques and equipment that meet ATS recommendations. Am Rev Respir Dis 1981;123:659-64.

10 Cockcroft DW. Measurement of airway responsiveness to inhaled histamine or methacholine: method of continuous aerosol generation and tidal breathing inhalation. In: Hargreave FE, Woolcock AJ, eds. Airway responsiveness: measurement and interpretation. Mississauga: Astra Pharmaceuticals Canada, 1985:22-8.

11 Hargreave FE, Dolovich J, Newhouse MT, Barnes PJ, Boulet $L-P, C a r t i e r ~ A$, et al. The assessment and treatment of asthma: a conference report. J Allergy Clin Immunol of asthma: a confer

12 Pepys J. Skin tests in diagnosis. In: Gell PGH, Coombs RRA, Lachmann PJ, eds. Clinical aspects of immunology. 3rd ed. Oxford: Blackwell Scientific Publications, 1975: 55-80.
13 Dolovich M, Chambers C, Newhouse M. Characterisation of 3 systems used to deliver pentamidine $(P)$ aerosol. [Abstract.] Am Rev Respir Dis 1990;141:A153.

14 Kramer MS, Feinstein AR. Clinical biostatistics. LIV. The biostatistics of concordance. Clin Pharmacol Ther 1981; 29:111-23.

15 Anderson SD, Schoeffel RE, Finney M. Evaluation of ultrasonically nebulised solutions for provocation testing in patients with asthma. Thorax 1983;38:284-91.

16 Boulet L-P, Legris C, Thibault L, Turcotte H. Comparative bronchial responses to hyperosmolar saline and methacholine in asthma. Thorax 1987;42:953-8.

17 Araki H, Sly D. Inhalation of hypertonic saline as a bronchial challenge in children with mild asthma and normal challenge in children with mild asthma and

18 Godard P, Aubas P, Calvayrac P, Taib J, Michel FB. Endoscopie et lavage bronciolo-alvéolaire chez l'asthmatique allergique. La Nouvelle Presse Médicale 1981; 10:3141-8.

19 Flint KC, Leung KBP, Hudspith BN, Brostoff J, Pearce FL, Johnson NMcI. Bronchoalveolar mast cells in extrinsic asthma: a mechanism for the initiation of antigen specific bronchoconstriction. BMJ 1985;291:923-6.

20 Wardlaw AJ, Cromwell O, Celestino D, et al. Morphological and secretory properties of bronchoalveolar lavage mast cells in respiratory diseases. Clin Allergy 1986;16:163-73.

21 Kelly C, Ward C, Stenton CS, Bird G, Hendrick DJ, Walters EH. Number and activity of inflammatory cells in bronchoalveolar lavage fluid in asthma and their relation to bronchoalveolar lavage fluid in asthma and their relation
airway hyperresponsiveness. Thorax 1988;43:684-92.

22 Howarth P, Djukanovic $R$, Wilson J, Wilson S, Roche W Holgate S. The influence of atopy on the endobronchial appearance in atopic asthma: a comparison between atopic asthma, atopic non-asthma and non-atopic non-asthma. [Abstract.] Am Rev Respir Dis 1990;141:A500.

23 Hargreave FE, Gibson PG, Denburg JA, Girgis-Gabardo A Dolovich J. Chronic cough: eosinophilic bronchitisresponse of sputum cells to corticosteroid (CS) and examination for variable airflow obstruction. [Abstract.] J Allergy Clin Immunol 1990;85:166.

24 Lundgren $\mathbf{R}$, Söderberg $M$, Hörstedt $P$, Stenling $R$. Morphological studies of bronchial mucosal biopsies from asthmatics before and after ten years of treatment with asthmatics before and after ten years of treat
inhaled steroids. Eur Respir J 1988;1:883-9.

25 Jeffery PK, Godfrey RW, Ảdelroth E, Johansson S-A. Effects of treatment on airway mucosal cell infiltrate and thickness of treatment on airway mucosal cell infiltrate and thickness
of reticular basement membrane in asthma. [Abstract.] of reticular basement membrane in

26 Diukanović R, Wilson JW, Britten KM, Wilson SJ, Roche WR, Howarth PH, et al. The effects of inhaled beclomethasone dipropionate (BDP) on inflammatory cells in the asthmatic airways. [Abstract.] J Allergy Clin Immunol 1991;87:172.

27 Chodosh S, Zaccheo CW, Segal MS. The cytology and histochemistry of sputum cells: preliminary differential counts in chronic bronchitis. Am Rev Respir Dis 1962; 85:635-48. 